\author{
Research Article
}

\title{
Actinobacteria from Greenwich Island and Dee Island: Isolation, diversity and distribution
}

\author{
Pek Lim Chu ${ }^{1}$, Chai Hoon $\mathrm{Khoo}^{1}$, Yoke Kqueen Cheah ${ }^{1 *}$ \\ 1 Department of Biomedical Science, Faculty of Medicine and Health Sciences, Universiti Putra Malaysia, 43400 UPM Serdang, Selangor Darul Ehsan, \\ Malaysia.
}

https://doi.org/10.28916/lsmb.1.1.2017.2

Received 1 September 2017, Revisions received 13 September 2017, Accepted 14 September 2017, Available online 14 September 2017

\begin{abstract}
Actinobacteria from underexplored and unusual environments have gained significant attention for their capability in producing novel bioactive molecules of diverse chemical entities. Streptomyces is the most prolific Actinobacteria in producing useful molecules. Rapid decline effectiveness of existing antibiotics in the treatment of infections are caused by the emergence of multidrug-resistant pathogens. Intensive efforts are urgently required in isolating non-Streptomyces or rare Actinobacteria and understanding of their distribution in the harsh environment for new drug discovery. In this study, pretreatment of soil samples with $1.5 \%$ phenol was used for the selective isolation of Actinobacteria from Dee Island and Greenwich Island. A high number of non-Streptomyces $(69.4 \%)$ or rare Actinobacteria was significantly recovered despite the Streptomyces (30.6\%), including the genera Micromonospora, Micrococcus, Kocuria, Dermacoccus, Brachybacterium, Brevibacterium, Rhodococcus, Microbacterium and Rothia. Reduced diversity and shift of distribution were observed at the elevated level of soil $\mathrm{pH}$. The members of genera Streptomyces, Micromonospora and Micrococcus were found to distribute and tolerate to a relatively high $\mathrm{pH}$ level of soil ( $\mathrm{pH}$ 9.4-9.5), and could potentially be alkaliphilic Actinobacteria. The phylogenetic analysis had revealed some potentially new taxa members of the genera Micromonospora, Micrococcus and Rhodococcus. Principal Component Analysis of soil samples was used to uncover the factors that underlie the diversity of culturable Actinobacteria. Water availability in soil was examined as the principal factor that shaped the diversity of the Actinobacteria, by providing a dynamic source for microbial interactions and elevated diversity of Actinobacteria.
\end{abstract}

Keywords: Rare Actinobacteria, distribution, Greenwich Island, Dee Island, Antarctica

\section{0}

\section{Introduction}

Actinobacteria is one of the major and dominant soil inhabitants. Presently, the phylum Actinobacteria comprised of more than 300 genera, representing one of the largest phyla within the domain Bacteria (Gao and Gupta 2012). Furthermore, the members of this phylum, especially the genus Streptomyces is the most studied group and also recognized as the most prolific producer of bioactive secondary metabolites with medicinal values, such as anti-tumor, anti-cancer, anti-infection properties (Berdy 2005; Hong et al. 2009). Rare actinobacteria are always referred to as strains that are difficult to isolate, maintain and might correspond to the unmatched source of new natural metabolites (Baltz, 2006). These rare Actinobacteria are contributing to the huge fraction of the commercialised antimicrobial agents. With the objective of discovering rare or novel species of Actinobacteria, selective isolation of Actinobacteria from the environmental samples has been started since few decades ago (Pisano et al. 1986; Pisano et al. 1989; Hayakawa et al. 1997;) and still being practiced extensively in the present (Zakharova et al. 2003; Hayakawa et al. 2004; Hong et al. 2009; Azman et al. 2015).

Antarctica is a pristine region on Earth that serves as a crucial barometer of global climate change. The human contact with this polar continent is less than two centuries of time. Antarctic continent is well known for extreme environmental conditions. These including the surroundings of extremely dryness and cold temperature, strong gusting wind, high UV radiation, continuous cycles of freeze/thawing, limited nutrient accessibility (Onofri et al. 2007; Margesin and Miteva 2011; Jadoon et al. 2013). The driest climate and coldest temperature had attributed to the ice formation that covers most of the lands and lakes of Antarctic continent. About $0.32 \%$ is ice-free region and is found to be the soil-forming area on this continent (Ugolini and Bockheim 2008). Microbes are the most abundant life that colonises the Antarctic ecosystems (Wynn-Williams 1996). Since last decades, more attention had received from researchers worldwide to study on the biodiversity of microbes and discovery of novel microbes from Antarctic continent (Nichols et al. 1999; Smith et al. 2006; Teixeira et al. 2010; Li et al. 2011; Muñoz et al. 2011; Gesheva and Negiota, 2012; Duarte et al. 2013; Lee et al. 2013). A general postulate is that the amplified impact of abiotic factors on microbial diversity is expected in the harsh environment of Antarctica, works to drive the community structure and composition (Barrett et al., 2006; Hogg et al., 2006).

\footnotetext{
* Correspondence: Department of Biomedical Science, Faculty of Medicine and Health Sciences, Universiti Putra Malaysia, 43400 UPM Serdang, Selangor Darul Ehsan, Malaysia.

e-Mail: ykcheah@upm.edu.my
}

(C) 2017 by the Author(s). Life Sciences, Medicine and Biomedicine (ISSN: 2600-7207) Published by Biome Journals. Wholly owned by Biome Scientia Sdn Bhd., previously by WWH Networks Sdn Bhd. Attribution-ShareAlike 4.0 International (CC BY-SA 4.0). This open access article is distributed based on the terms and conditions of the Creative Commons Attribution license https://creativecommons.org/licenses/by-sa/4.0/ 
The phylogenetic marker, 16S ribosomal RNA (rRNA) gene was used to define the species, in characterizing the spatial patterns of microbial distribution. Metagenomics analysis had revealed a high level of bacterial diversity in the Antarctic soils and the dominant phyla of bacteria were Actinobacteria, Proteobacteria and Firmicutes, and a large number of anaerobic bacteria (Teixeira et al. 2010). Actinobacteria was reported to be one of the common components in the Antarctic soil of Lake Wellman area, Darwin Mountains, with three subphyla and 15 genera (Aislabie et al. 2013). This finding also indicates that Antarctic environments presented as a natural reservoir that harbour large number of potentially new and yet-tobe-cultured microbes. Hence, Antarctica has now emerged as a new hope in isolating rare or novel Actinobacteria, enhanced by the elevated environmental stressors in Antarctic continent. The diversity of the difficult-to-culture or rare Actinobacteria influenced by the by abiotic environmental gradients will gain our insight on their survival strategies in colonizing the harsh Antarctic conditions.

Greenwich Island lies between Robert Island and Livingstone Island in the South Shetland Islands (Ivanov et al. 2009). While Dee Island is an ice-free island located between Greenwich Island and Aitcho Island. The presence and diversity of Actinobacteria population on these lands was investigated using selective isolation approach. The factor that is underlying the distribution of these Actinobacteria was also revealed. This study described the diversity and distribution of Streptomyces and rare Actinobacteria from Greenwich Island and Dee Island, Antarctica in relation to the abiotic environmental gradients.

\subsection{Materials and methods}

\section{$2.1 \quad$ Environmental sampling}

Soil samples were collected during the XI Ecuadorian Antarctic Expedition to the Research Station "Pedro Vicente Maldonado", Greenwich Island, South Shetland Islands in 2007 as shown in Figure. 1 (coordinates: 62'24' 18.7'S to 62'24' $32.4^{\prime \prime} \mathrm{S}$ and $59^{\circ} 44^{\prime} 13.2^{\prime \prime} \mathrm{W}$ to $59^{\circ} 45^{\prime} 39.3^{\prime \prime} \mathrm{W}$ ). Top soil samples, the upper $20 \mathrm{~cm}$ layer were collected after removing the top 2-3 cm layer, from five different sites within Greenwich Island. Soils were collected into sterile plastic bags by using an aseptic metal trowel and kept in dark for transport to Malaysia. Upon arrival to the research lab, the soils were kept at $-20^{\circ} \mathrm{C} .15$ soil samples collected from five different locations at South Shetland Island, Antarctica, were used in this study. The specific

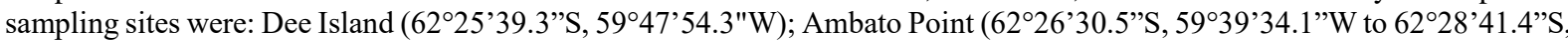

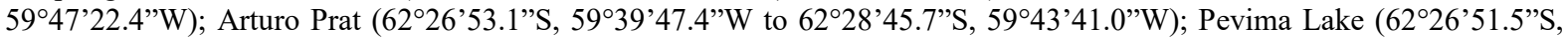
$59^{\circ} 43^{\prime} 33.8^{\prime \prime} \mathrm{W}$ to $\left.62^{\circ} 26^{\prime} 55.1^{\prime \prime} \mathrm{S}, 59^{\circ} 43^{\prime} 38.4^{\prime \prime} \mathrm{W}\right)$ and Greenwich Island $\left(62^{\circ} 26^{\prime} 59.5^{\prime \prime} \mathrm{S}, 59^{\circ} 43^{\prime} 53.3^{\prime \prime} \mathrm{W}\right.$ to $62^{\circ} 27^{\prime} 02.0^{\prime \prime} \mathrm{S}$, $\left.59^{\circ} 44^{\prime} 12.1^{\prime \prime} \mathrm{W}\right)$. Soil $\mathrm{pH}$ was measured by a $1: 5$ sample-to-deionized water slurry ratio and recording $\mathrm{pH}$ using a $\mathrm{pH}$ electrode (Hanna, USA). Soil temperature was measured using a digital thermometer (Hanna, USA). The UV-A and UV-B radiation were measured using a radiometer (UVP, UK).

\subsection{Selective isolation of Actinobacteria from soils}

One gram of each soil sample was air dried for 7 days. The air-dried soils were ground with mortar pestle into fine particles. Selective isolation of Actinobacteria was performed by $1.5 \%$ phenol pretreatment of soil samples at $30^{\circ} \mathrm{C}$ for $30 \mathrm{~min}$ (Pisano et al. 1986). The pretreated soils samples were serially diluted up to $10-4$ with sterile $25 \%$ Ringer's solution. One hundred microliters of each diluted suspension (10-1, 10-2, 10-3 and 10-4) was spread onto different selective isolation media. Each diluted soil suspension was spread onto five different isolation media: ISP media 2 (Shirling and Gottlieb 1966), starch casein agar (SCA; Küster and Williams 1964), humic acid-vitamin agar (HVA; Hayakawa and Ohara 1987), Streptomyces agar (SA; Atlas, 1993) and Actinomycetes isolation agar (AIA; Atlas 1993). All of the media were supplemented with nalidixic acid $(20 \mathrm{mg} / \mathrm{L})$, nystatin $(50 \mathrm{mg} / \mathrm{L})$ and cycloheximide $(50 \mathrm{mg} / \mathrm{L})$ (Williams and Davies 1965). The isolation plates were incubated at $28^{\circ} \mathrm{C}$ for one up to eight weeks. Purified bacterial isolates were maintained on ISP medium 2 agar slants at room temperature and in $20 \%$ glycerol at $-20^{\circ} \mathrm{C}$.

\subsection{Genomic DNA extraction from pure cultures}

Genomic DNA extraction was performed by using a protocol adapted from the Current Protocols in Molecular Biology with some modifications (Wilson 2001). In brief, bacterial broth culture was spun to collect cell pellet. The cell pellet was lysed with Solution I ((50mM glucose; $25 \mathrm{mM}$ Tris-HCl; 10mM EDTA; $\mathrm{pH} 8.0)$, SDS buffer and proteinase K, and treated with RNase. DNA was extracted from cell lysate through phenol/chloroform/isoamyl alcohol (25:24:1) purification. The aqueous layer obtained was added with sodium acetate to remove histone protein bound to DNA. Finally, the DNA was collected by ethanol precipitation and stored at $-20^{\circ} \mathrm{C}$.

\section{$2.4 \quad 23 S$ rRNA PCR amplification and screening for Actinobacteria}

PCR amplification of the large insert stretch in 23S rRNA gene that was specific for Actinobacteria was performed. It was carried out in Eppendorf Mastercycler (Eppendorf, Hamburg, Germany). Degenerated primers were used: 23S-f 5'CCGANAGGCGTAGBCGATGG-3' and 23S-r 5'-CCWGWGTYGGTTTVSGGTA-3' (Gao and Gupta 2005). The final 30 $\mu 1$ PCR reaction mixture contained: 20-200 ng bacteria genomic DNA, 1X PCR buffer with $2 \mathrm{mM} \mathrm{MgCl} 2,0.67 \mathrm{mM}$ dNTPs mixture, $0.33 \mu \mathrm{M}$ of each primer and $1 \mathrm{U}$ of Taq polymerase (Genet Bio, Korea). The thermal profile was: pre-denaturation at $97^{\circ} \mathrm{C}$ for $5 \mathrm{~min}$; followed by 30 cycles of: denaturation at $97^{\circ} \mathrm{C}$ for $30 \mathrm{~s}$, annealing at $55^{\circ} \mathrm{C}$ for $30 \mathrm{~s}$, extension at $72^{\circ} \mathrm{C}$ for 1 $\min$; and a final extension at $72^{\circ} \mathrm{C}$ for $15 \mathrm{~min}$. 


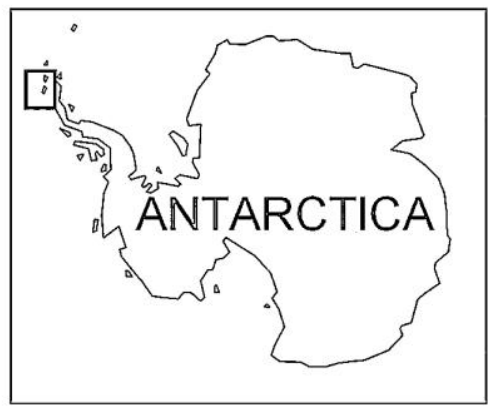

a

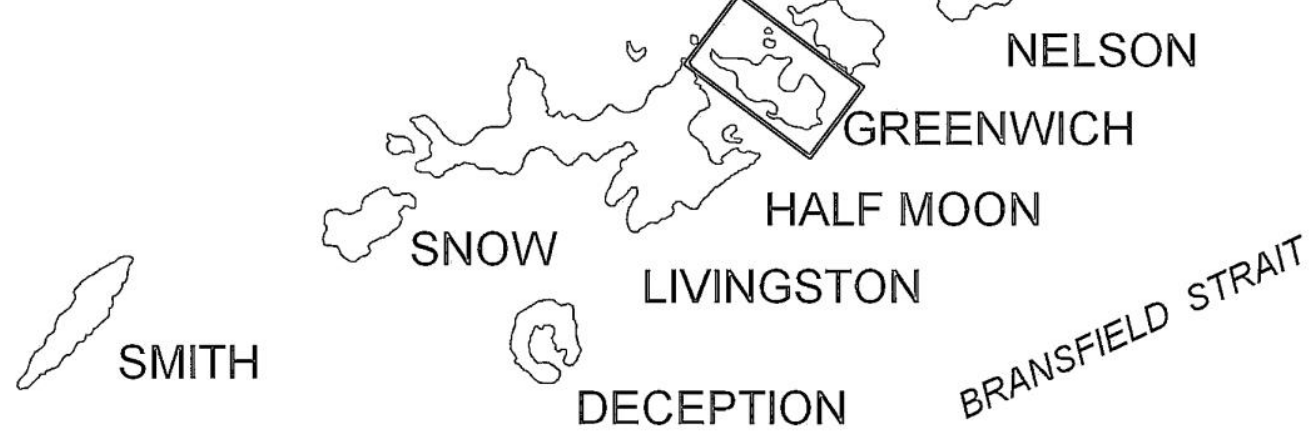

m LOW

GRAHAM

a)

LAND

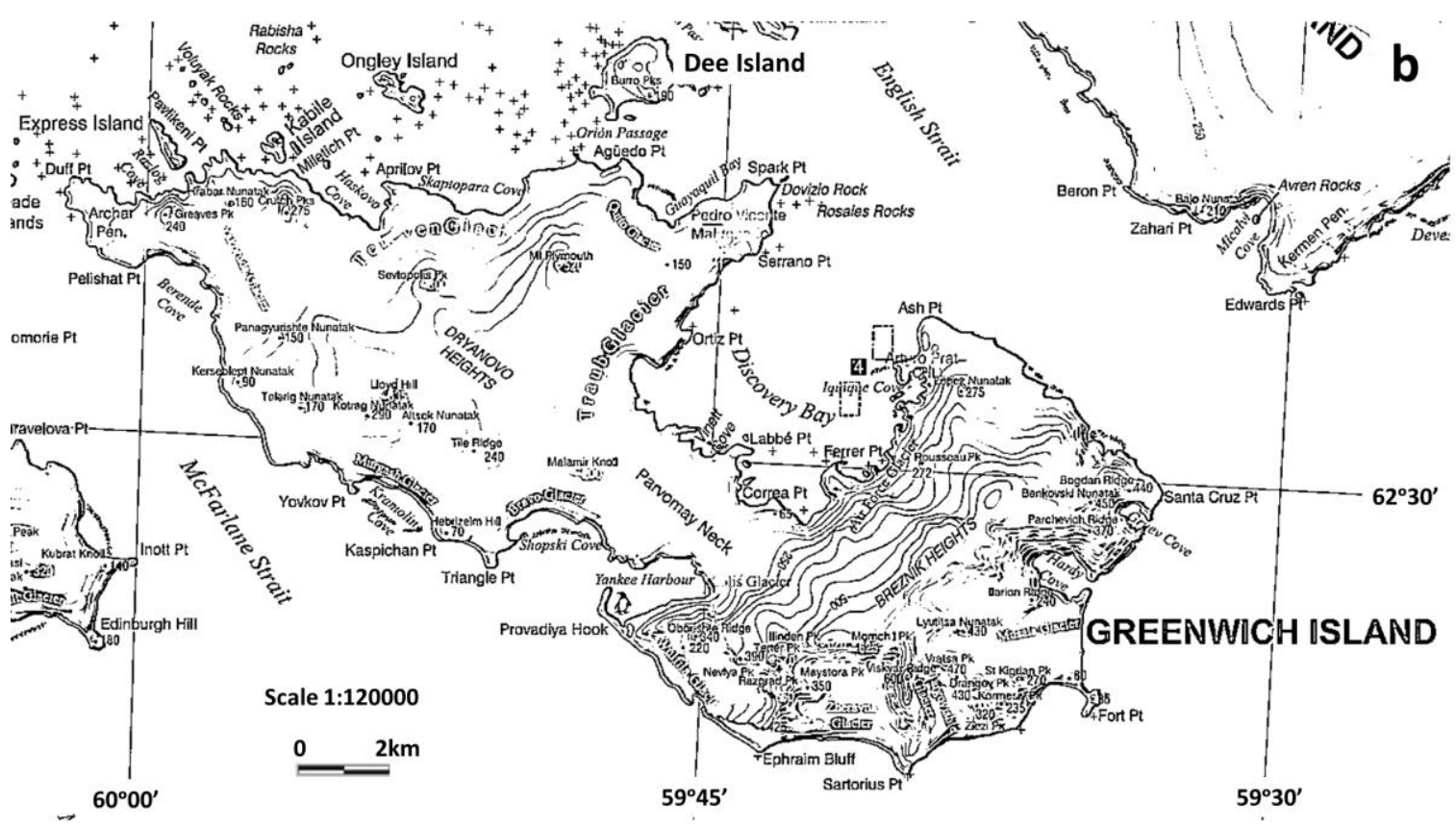

Figure 1: Map of the sampling sites, (a) The Antarctic continent with the Antarctic Peninsula in relief. The box indicated the location of Greenwich Island and Dee Island in South Shetland Islands and (b) Greenwich Island and Dee Island. (Adapted from Ivanov LL, 2009).

From the 23S rRNA gene amplification profile, bacterial isolates with the expected size of products were subsequently selected for 16S rRNA amplification. The PCR primer pair EuBac 27F and EuBac 1492R (Lane 1991) were used to perform PCR amplification of 16S rRNA gene by using the Eppendorf Mastercycler (Eppendorf, Hamburg, Germany). The final PCR reaction mixture consisted: 20-200 ng bacteria genomic DNA, 1X PCR buffer with $2 \mathrm{mM} \mathrm{MgCl} 2,0.67 \mathrm{mM}$ dNTPs mixture, $0.33 \mu \mathrm{M}$ of each primer and $1 \mathrm{U}$ of Taq polymerase (Genet Bio, Korea). The thermal profile was: pre-denaturation at 
$95^{\circ} \mathrm{C}$ for $5 \mathrm{~min}$; followed by 30 cycles of: denaturation at $95^{\circ} \mathrm{C}$ for $50 \mathrm{~s}$, annealing at $52^{\circ} \mathrm{C}$ for $1 \mathrm{~min}$, extension at $72^{\circ} \mathrm{C}$ for 1.5 min; and a final extension at $72^{\circ} \mathrm{C}$ for $10 \mathrm{~min}$.

2.6 DNA sequencing of amplified $16 S$ rRNA gene sequences of Actinobacteria isolates and phylogenetic analysis

The PCR products of 16S rRNA gene amplification were purified by the MEGAquick-spinTM PCR and agarose gel DNA extraction kit, using protocols provided by the manufacturer (iNtRON Biotechnology Inc). The purified PCR products were sequenced using BigDye ${ }^{\circledR}$ Terminator Cycle Sequencing Chemistry 3.1 technique and a Genetic Analyzer ABI Prism 3100 (Applied Biosystem). The forward and reverse sequences of 16S rRNA of each Actinobacteria isolates were assembled manually to form an almost complete 16S rRNA gene sequence. The almost complete 16S rRNA gene sequences were subjected to BLASTN program to search for closest identities. The corresponding sequences of the representatives of the relevant genera were retrieved from GenBank/EMBL/DDBJ databases (NCBI, USA). Phylogenetic trees were constructed using MEGA version 6.0 (Tamura et al. 2013) by neighbour-joining method (Saitou and Nei 1987). The evolutionary distances were computed using the Maximum Composite Likelihood method (Tamura et al. 2004) and the bootstrap value were calculated by 1000 replicates (Felsenstein 1985). The calculation of pairwise 16S rRNA gene sequence similarities were performed using the EzTaxon-e server (http://eztaxon-e.ezbiocloud.net/) (Kim et al. 2012).

Nucleotide sequence accession numbers

The 16S rRNA gene sequences of Actinobacteria isolates in this study were deposited in the NCBI Genbank database, under accession numbers of KJ743996-KJ744031.

\section{$2.8 \quad$ Statistical analysis}

Principal component analysis (PCA) was performed on the relative abundance and diversity of Actinobacteria isolated from each soil samples at genera level, using XLSTAT software version 2014.1.09 (Paris, France MacOS ed). The effect of the presence of water activity, skua area and characteristics of soil were investigated based on the biplot created and examined for the factors that drive the diversity and distribution of Actinobacteria on Greenwich Island and Dee Island.

\subsection{Results}

\subsection{Selective isolation of Actinobacteria}

A total of 50 isolates of bacteria were isolated from 15 soil samples collected from South Shetland Island, Antarctica. These isolates were discriminated to be Actinobacteria and other bacteria using the 23S rRNA PCR amplification profiling. The specificity of the 23S rRNA primers was validated by DNA sequencing of representative isolates from the group of nonactinobacteria in $23 \mathrm{~S}$ rRNA profile. Through the $23 \mathrm{~S}$ rRNA profiling, $72 \%$ (36 out of 50) of the isolates were Actinobacteria, and the remaining $28 \%$ (14 out of 50) was of non-Actinobaceria (Table 1).

\subsection{Culturable Actinobacteria}

Around $40 \%$ of the Actinobacteria isolates were visible during the first week of incubation while most of the Actinobacteia isolates were only visible during or after the fourth week of incubation. The numbers of culturable Actinobacteria isolated from each soil sample was found to be higher than the non-Actinobacteria, except for the soil samples labeled as 62,71 and 96, and there were no culturable isolates of bacteria from the soil samples label as 63, 77 and 103 (Table 1). Low number or absence of culturable bacteria from the soil samples could due to 1) absent of phenol-resistant bacteria, 2) inappropriate culture medium to recover the phenol-resistant bacteria. The highest number of Actinobacteria isolates was recorded on the soil sample labeled as 111, which was collected from Greenwich Island.

Actinobacteria isolates with the colony morphologies characteristic belong to the genus Streptomyces were obtained from each sampling site except Dee Island. The phenotypic characteristic included the formation of powdery and chalky aerial mycelium. Besides, orange-pigmented colonies without aerial mycelium formation were also obtained from three sampling sites, which belong to the genus Micromonospora. Additional features found on these colonies were blackened colony surface due to the presence of spores (Bredholdt et al. 2007; Becerril-Espinosa et al. 2013).

\subsection{Diversity of culturable Actinobacteria}

In total, 36 Actinobacteria isolates were recovered from 15 soil samples collected at South Shetland Island. Based on the 16S rRNA gene sequences, the rare Actinobacteria isolates were distributed in the suborders of Micrococcineae, Streptomycineae, Micromonosporineae and Corynebacterineae. The most abundant genus was Streptomyces (30.6\%). Abundance of non-Streptomyces genera were also identified, including the genera Micrococcus (22.2\%), Kocuria (16.7\%), Micromonospora (8.3\%), Brachybacterium (5.5\%), Dermacoccus (5.5\%), Brevibacterium (2.8\%), Rhodococcus $(2.8 \%)$, Microbacterium (2.8\%) and Rothia (2.8\%) (Tables 2, 3).

Streptomyces species were recovered from all of the sampling sites except for Dee Island (Table 2). The high species abundance was followed by Micrococcus after Streptomyces, which were identified from all five sampling sites in this study. In the present work, the HVA was the most efficient isolation medium in recovering Actinobacteria from soil samples, by recovering 8 out of 10 genera of Actinobacteria identified (Table 3). 
Table 1: Physical and chemical properties of soils and numbers of Actinobacteria and bacteria isolates from 15 soil samples

\begin{tabular}{|c|c|c|c|c|c|c|c|c|c|}
\hline \multirow{2}{*}{ Sampling site } & & \multirow{2}{*}{$\begin{array}{l}\text { Soil } \\
\text { reference }\end{array}$} & \multirow{2}{*}{ Soil temperature $\left({ }^{\circ} \mathrm{C}\right)$} & \multirow{2}{*}{$\mathrm{pH}$} & \multicolumn{2}{|c|}{ Solar radiation $\left(\mathrm{mV} / \mathrm{cm}^{2}\right)$} & \multicolumn{2}{|c|}{ Numbers of isolates } & \multirow{2}{*}{ Total } \\
\hline & & & & & UVA (20) & UVB (20) & Actinobacteria & Other bacteria & \\
\hline $\begin{array}{l}\text { Dee Island } \\
\left(62^{\circ} 25^{\prime} 39.3 ” S,\right. \\
\left.59^{\circ} 47^{\prime} 54.3 " \mathrm{~W}\right)\end{array}$ & & 53 & 10.2 & 8.7 & 5.83 & 6.84 & 2 & 1 & 3 \\
\hline $\begin{array}{l}\text { Ambato Point } \\
\left(62^{\circ} 26^{\prime} 30.5 ” S,\right. \\
59^{\circ} 39^{\prime} 34.1 ” \mathrm{~W} \\
62^{\circ} 28^{\prime} 41.4 ” \mathrm{~S}, \\
\left.59^{\circ} 47^{\prime} 22.4 ” \mathrm{~W}\right)\end{array}$ & to & $\begin{array}{l}62 \\
63 \\
64\end{array}$ & $\begin{array}{l}16.1 \\
11.8 \\
9.5\end{array}$ & $\begin{array}{l}9.5 \\
9.4 \\
9.5\end{array}$ & $\begin{array}{l}3.57 \\
4.12 \\
4.08\end{array}$ & $\begin{array}{l}4.82 \\
6.81 \\
2.4\end{array}$ & $\begin{array}{l}1 \\
- \\
5\end{array}$ & $\begin{array}{l}3 \\
- \\
2\end{array}$ & 11 \\
\hline $\begin{array}{l}\text { Arturo Prat } \\
\left(62^{\circ} 26^{\prime} 53.1^{\prime \prime S},\right. \\
59^{\circ} 39^{\prime} 47.4 ” \mathrm{~W} \\
62^{\circ} 28^{\prime} 45.7 ” \mathrm{~S}, \\
\left.59^{\circ} 43^{\prime} 41.0^{\prime \prime} \mathrm{W}\right)\end{array}$ & to & $\begin{array}{l}68 \\
70 \\
71\end{array}$ & $\begin{array}{l}7.3 \\
7.3 \\
9\end{array}$ & $\begin{array}{l}8.4 \\
8.2 \\
8.2\end{array}$ & $\begin{array}{l}5.69 \\
4.71 \\
5.12\end{array}$ & $\begin{array}{l}16.1 \\
4.54 \\
4.2\end{array}$ & $\begin{array}{l}3 \\
3 \\
1\end{array}$ & $\begin{array}{l}- \\
- \\
2\end{array}$ & 9 \\
\hline $\begin{array}{l}\text { Pevima Lake } \\
\left(62^{\circ} 26^{\prime} 51.5 ” \mathrm{~S},\right. \\
59^{\circ} 433^{\prime} 33.8^{\prime \prime} \mathrm{W} \\
62^{\circ} 26^{\prime} 55.1 ” \mathrm{~S}, \\
\left.59^{\circ} 43^{\prime} 38.4 ” \mathrm{~W}\right)\end{array}$ & to & $\begin{array}{l}96 \\
97 \\
98 \\
100\end{array}$ & $\begin{array}{l}4.3 \\
9.5 \\
8.9 \\
8.9\end{array}$ & $\begin{array}{l}7.8 \\
7.7 \\
7.5 \\
7.6\end{array}$ & $\begin{array}{l}0.65 \\
0.56 \\
0.58 \\
0.94\end{array}$ & $\begin{array}{l}0.53 \\
0.42 \\
0.42 \\
1.08\end{array}$ & $\begin{array}{l}- \\
3 \\
5 \\
3\end{array}$ & $\begin{array}{l}2 \\
- \\
1 \\
-\end{array}$ & 14 \\
\hline $\begin{array}{l}\text { Greenwich Island } \\
\left(62^{\circ} 26^{\prime} 59.5^{\prime \prime} \mathrm{S},\right. \\
59^{\circ} 43^{\prime} 53.3 \text { ' } \\
62^{\circ} 27^{\prime} 02.0^{\prime \prime} \mathrm{S}, \\
59^{\circ} 44^{\prime} 12.1 \text { 'W) }\end{array}$ & to & $\begin{array}{l}76 \\
77 \\
103 \\
111\end{array}$ & $\begin{array}{l}2.9 \\
2.6 \\
5 \\
4.8\end{array}$ & $\begin{array}{l}7.6 \\
7.6 \\
7.5 \\
7.4\end{array}$ & $\begin{array}{l}11.01 \\
1.61 \\
3.52 \\
3.46\end{array}$ & $\begin{array}{l}1.32 \\
0.01 \\
4.86 \\
4.63\end{array}$ & $\begin{array}{l}3 \\
- \\
- \\
7\end{array}$ & $\begin{array}{l}1 \\
- \\
- \\
2\end{array}$ & 13 \\
\hline & & & & & Total & & 36 & 14 & 50 \\
\hline
\end{tabular}


The influence of soil alkalinity on the distribution of Actinobacteria species was studied. As shown in Figure. 2, 9 out of 10 genera of Actinobacteria identified in this study were successfully recovered from soils of slightly alkaline ( $\mathrm{pH}$ 7.4-7.8), accounted for the highest diversity of soil Actinobacteria. While for the soils of moderately alkaline ( $\mathrm{pH} 7.9-8.4)$, five Actinobacteria genera were isolated. The least count of Actinobacteria genera (three) was obtained from soils of highly alkaline ( $\mathrm{pH} \geq 8.5$ ). The members of Kocuria were found in the soil of slightly and moderately alkaline. While the members of Rothia were only recovered from the soil of moderately alkaline. Interestingly, the members of Streptomyces, Micrococcus and Micromonospora were found in the soils of all three types of alkalinity.

Table 2 List of Actinobacteria isolates in this study

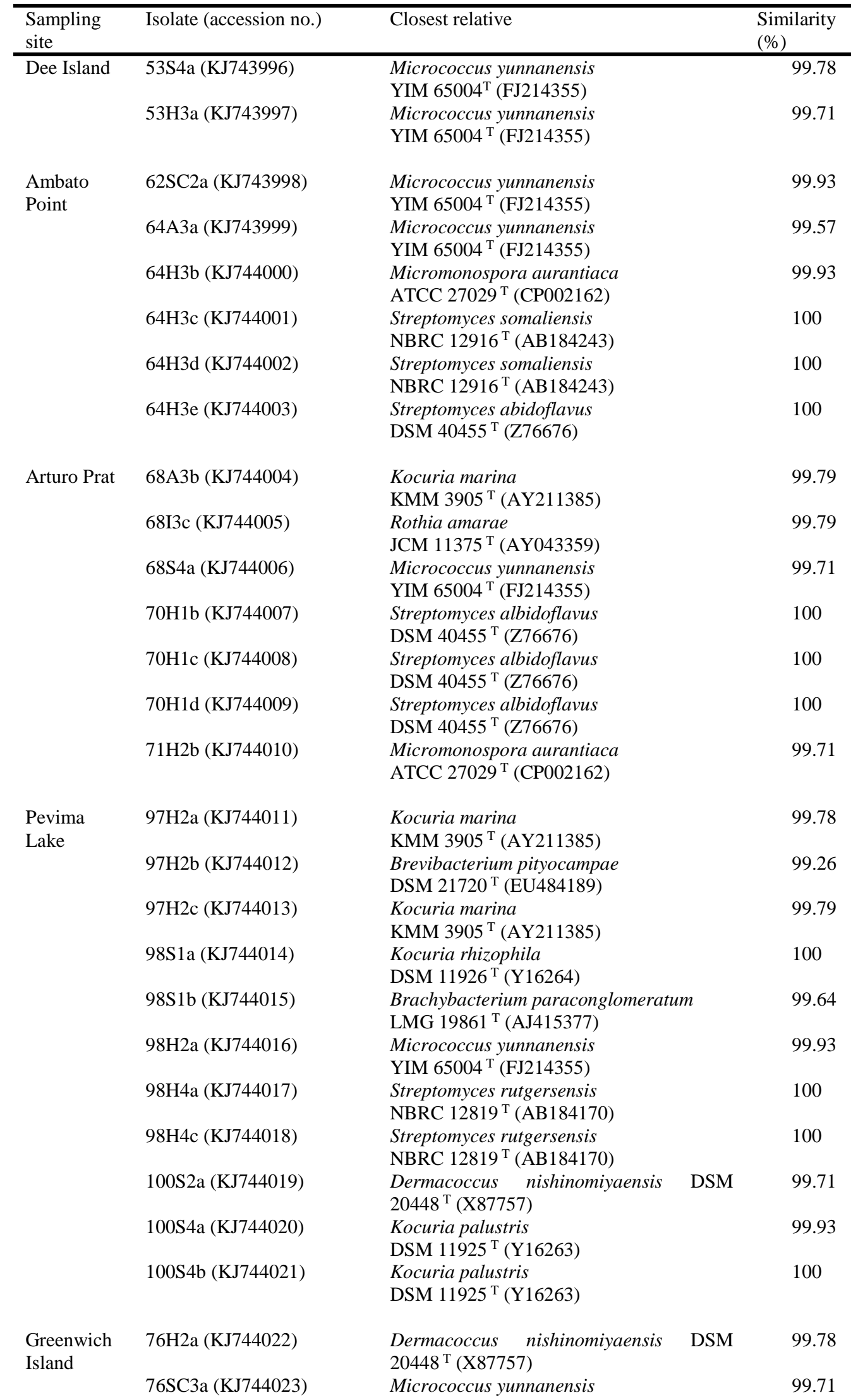




\begin{tabular}{|c|c|c|}
\hline \multirow[b]{2}{*}{ 76A3b (KJ744024) } & YIM $65004^{\mathrm{T}}$ (FJ214355) & \multirow[b]{2}{*}{99.86} \\
\hline & Micrococcus yunnanensis & \\
\hline 111S1a (KJ744025) & $\begin{array}{l}\text { YIM } 65004^{\mathrm{T}}(\mathrm{FJ} 214355) \\
\text { Brachybacterium nesterenkovii DSM } 9573\end{array}$ & 99.64 \\
\hline & ${ }^{\mathrm{T}}(\mathrm{X} 91033)$ & \\
\hline \multirow[t]{2}{*}{ 111H2a (KJ744026) } & Micromonospora eburnea & \multirow[t]{2}{*}{98.83} \\
\hline & $\mathrm{LK} 2-10^{\mathrm{T}}(\mathrm{AB} 107231)$ & \\
\hline \multirow[t]{2}{*}{$111 \mathrm{H} 2 \mathrm{c}(\mathrm{KJ} 744027)$} & Rhodococcus yunnanensis & \multirow[t]{2}{*}{99.13} \\
\hline & YIM $70056^{\mathrm{T}}(\mathrm{AY} 602219)$ & \\
\hline \multirow[t]{2}{*}{ 111H3b (KJ744028) } & Microbacterium saccharophilum & \multirow[t]{2}{*}{99.42} \\
\hline & $\mathrm{K}-1^{\mathrm{T}}(\mathrm{AB} 736273)$ & \\
\hline \multirow[t]{2}{*}{ 111H3g (KJ744029) } & Streptomyces albidoflavus & \multirow[t]{2}{*}{100} \\
\hline & DSM $40455^{\mathrm{T}}(\mathrm{Z} 76676)$ & \\
\hline \multirow[t]{2}{*}{ 111H3h (KJ744030) } & Streptomyces albidoflavus & \multirow[t]{2}{*}{100} \\
\hline & DSM $40455^{\mathrm{T}}(\mathrm{Z} 76676)$ & \\
\hline \multirow[t]{2}{*}{ 111H3I (KJ744031) } & Streptomyces albidoflavus & \multirow[t]{2}{*}{100} \\
\hline & DSM $40455^{\mathrm{T}}(\mathrm{Z} 76676)$ & \\
\hline
\end{tabular}

Table 3: Taxa of Actinobacteria recovered on five different isolation media

\begin{tabular}{llll}
\hline Culture media & Families & Genera & $\begin{array}{l}\text { Number of } \\
\text { isolates }\end{array}$ \\
\hline ISP2 agar & Micrococcaceae & Rothia & 1 \\
Starch casein agar & Micrococcaceae & Micrococcus & 2 \\
Actinomycetes isolation & Micrococcaceae & Micrococcus & 2 \\
agar & & Kocuria & 1 \\
Streptomyces agar & Micrococcaceae & Micrococcus & 2 \\
& Dermacoccaceae & Kocuria & 3 \\
& Dermabacteraceae & Brachybacterium & 1 \\
Humic acid-vitamin agar & Streptomycetaceae & Streptomyces & 11 \\
& Micromonosporaceae & Micromonospora & 3 \\
& Micrococcaceae & Micrococcus & 2 \\
& & Kocuria & 2 \\
& Brevibacteriaceae & Brevibacterium & 1 \\
& Dermacoccaceae & Dermacoccus & 1 \\
& Nocardiaceae & Rhodococcus & 1 \\
& Microbacteriaceae & Microbacterium & 1 \\
& & & \\
& &
\end{tabular}




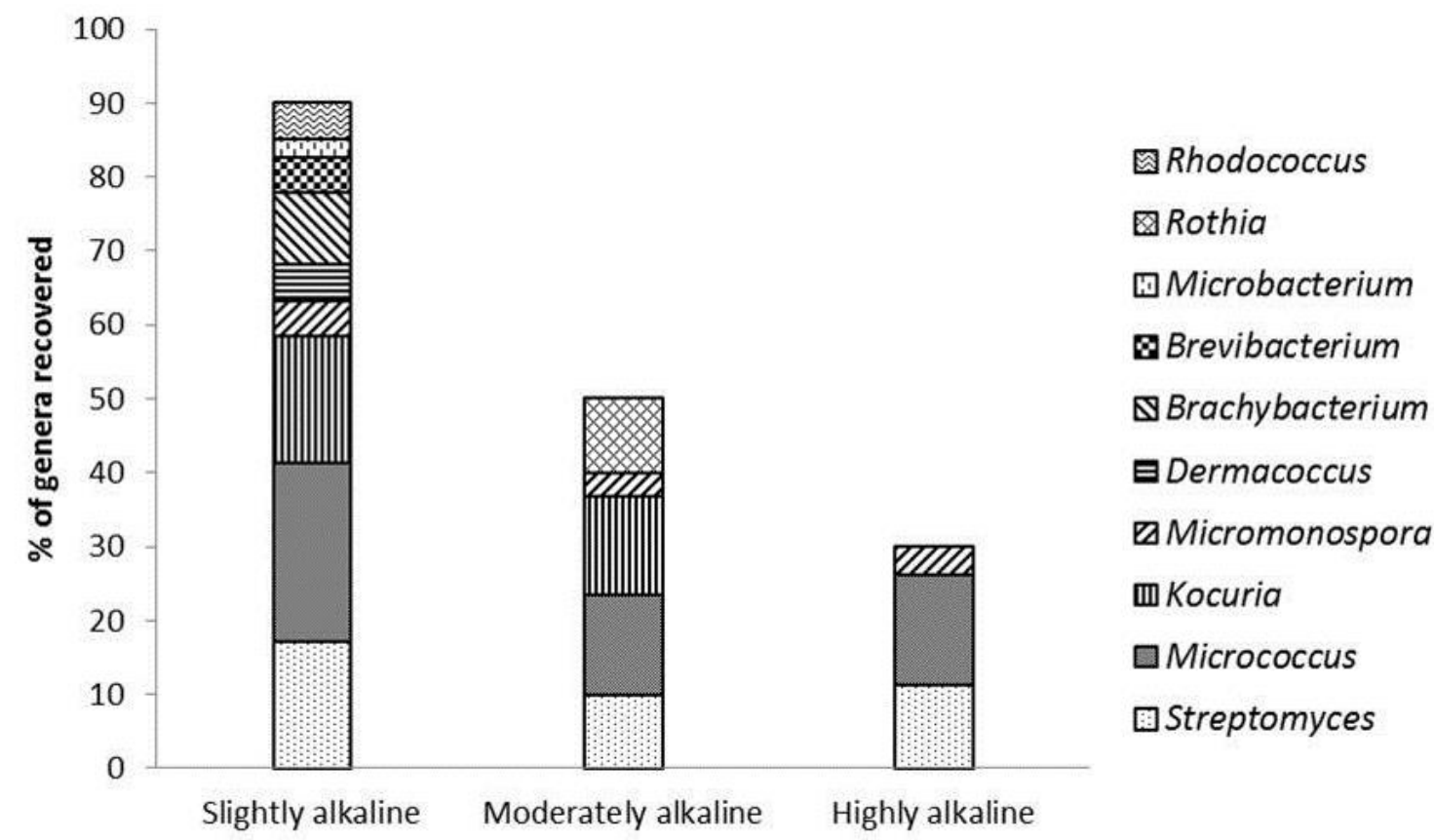

Figure. 2 Percentage of total recovery of genera of Actinobacteria from soils of different alkalinity. Abundance of each genus recovered from different alkalinity was showed in each bar strip

Phylogenetic trees were constructed based on 16S rRNA sequences to investigate the evolutionary relationships between the Actinobacteria isolates in this study and their closest taxa members. Streptomyces isolates from Ambato Point, Arturo Prat and Greenwich Island were forming a distinct subclade with the type strains of Streptomyces somaliensis and Streptomyces albidoflavus (Figure. 3a), delineated from other Streptomyces species. The Streptomyces isolates from Pevima Lake were forming a cluster that was represented by Streptomyces rutgersensis. Other than that, putative new species of non-Streptomyces were identified in this study. All of the isolates of Micrococcus were found to be closely related to Micrococcus yunnanensis and shared 16S rRNA gene similarity ranging from 99.5-99.93\% (Figureure. 3b). Interestingly, three isolates, namely 64A3a, 62SC2a and 76A3b, formed a distinct cluster out of the subclade of M. yunnanensis that comprised of all other isolates of Micrococcus, which could represent new taxa of M. yunnanensis. A putative new species of Micromonospora were identified, namely, isolate $111 \mathrm{H} 2 \mathrm{a}$, by sharing <99\% of $16 \mathrm{~S}$ rRNA gene similarity with Micromonospora eburnea, and formed a phyletic lineage out from the subclade of M. eburnea (Figure 3c). A Rhodococcus isolate with no mycelial growth was closely related to Rhodococcus yunnanensis by sharing $99.13 \%$ 16S rRNA gene similarity. However, it formed a phyletic lineage out from the subclade represented by type strain of Rhodococcus yunnanensis in the phylogenetic tree (Figure 3d), representing a putative new taxon. By sharing 99.78-99.79\%, 99.71-99.93\% and 100\% 16S rRNA gene similarities, the isolates were clustered within the subclades represented by Kocuria marina, Kocuria palustris and Kocuria rhizophila respectively (Figure 3e). The isolates of the genera Brachybacterium, Dermacoccus, Brevibacterium, Microbacterium and Rothia were clustered together with their closest relatives (Figure 3f, 3g, 3h, 3i and 3j). 
a

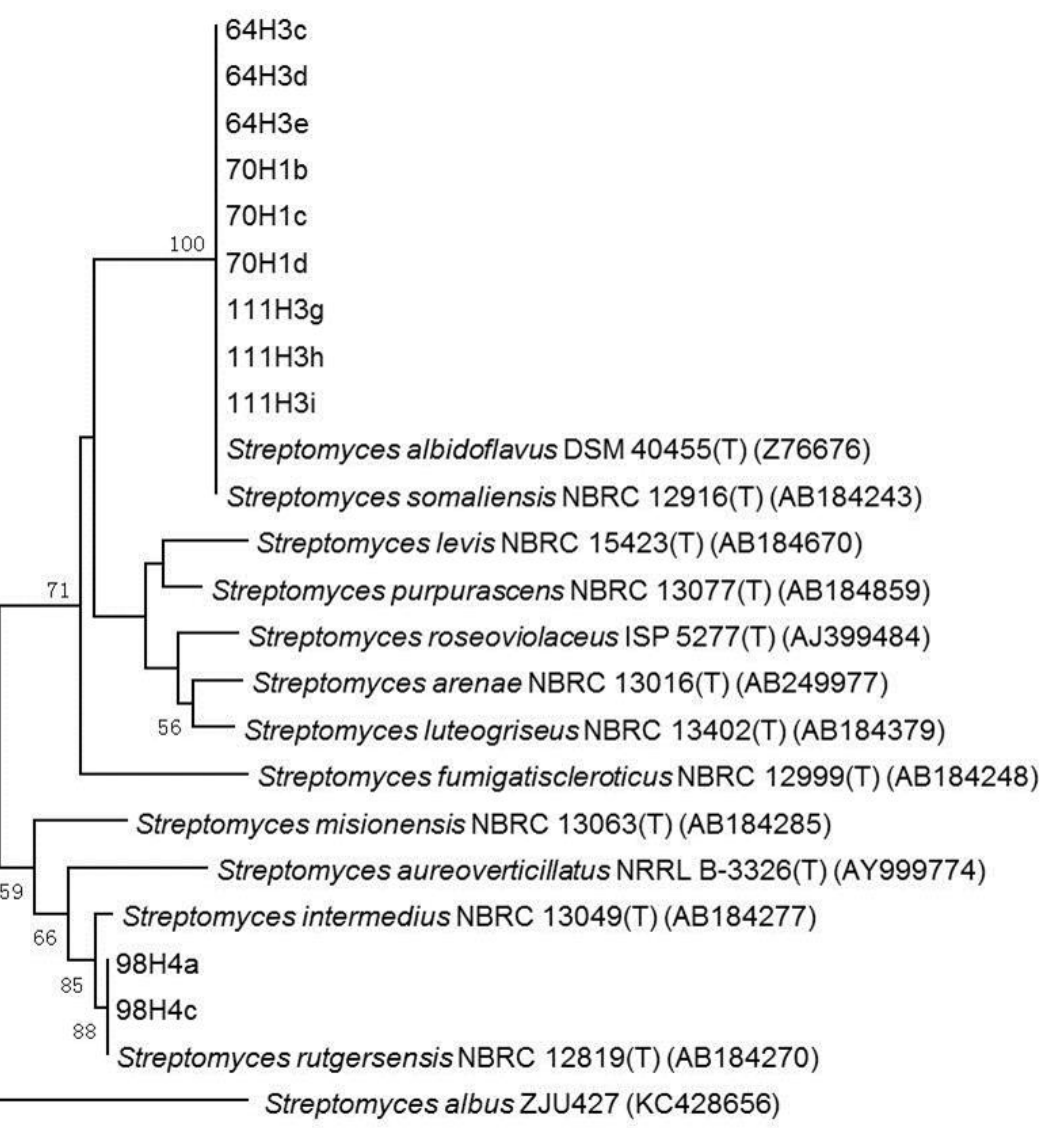

$\longmapsto$

b

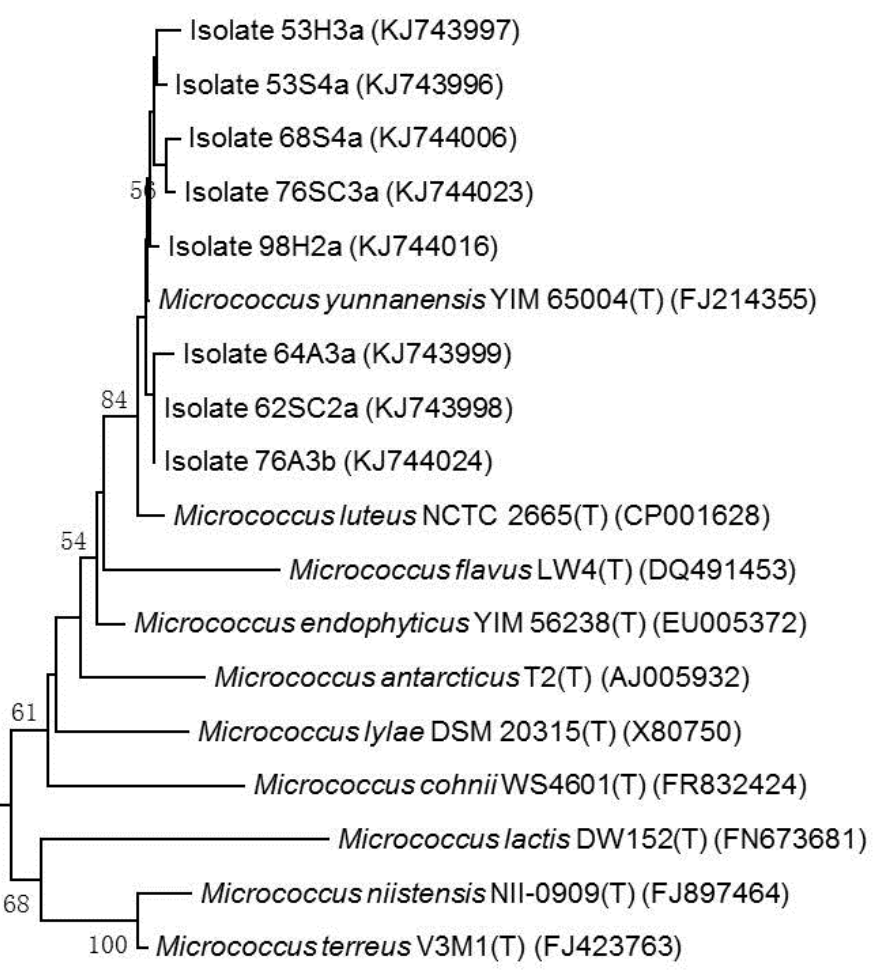

Streptomyces albus ZJU427 (KC428656) 
c

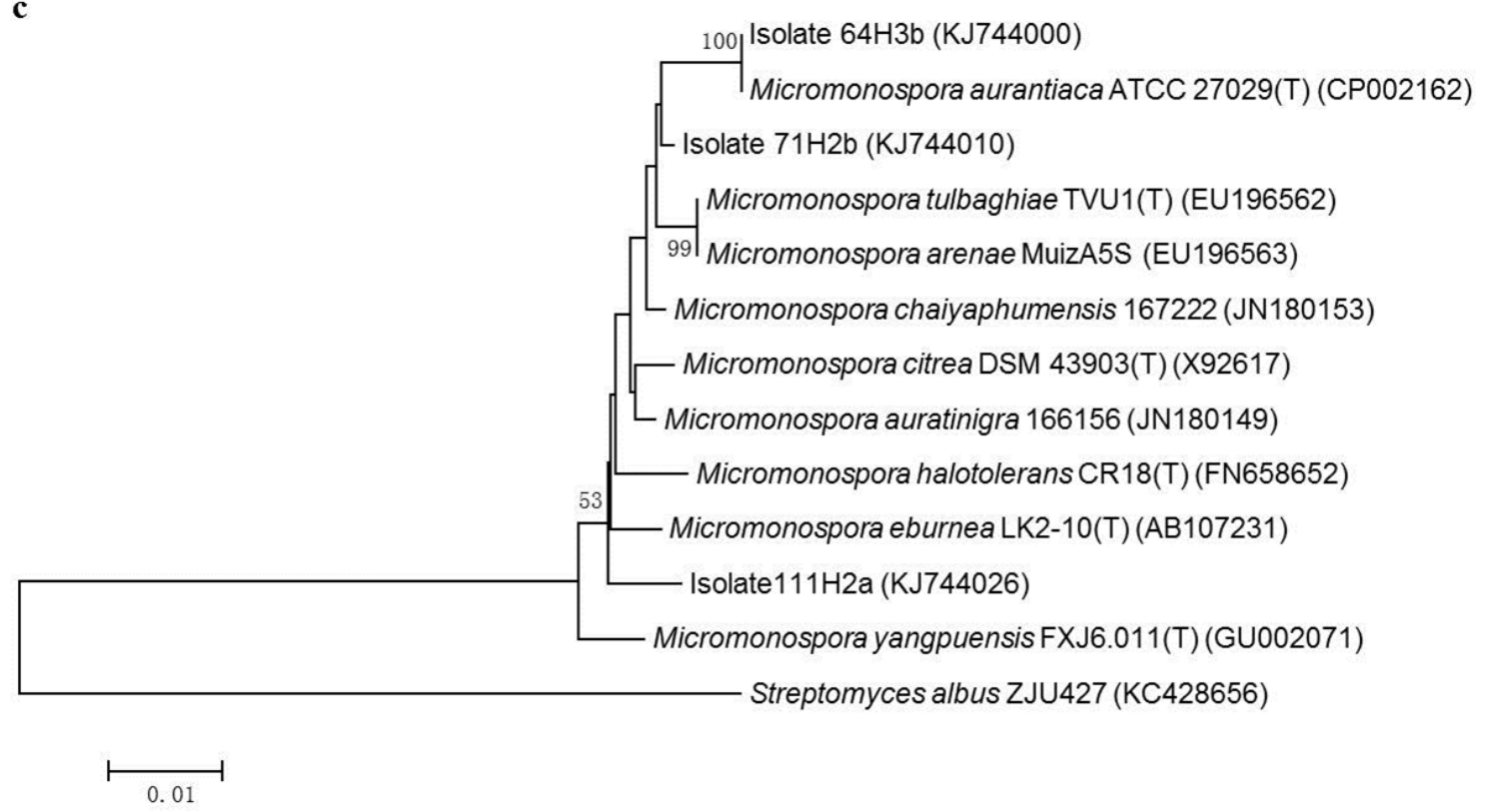

d

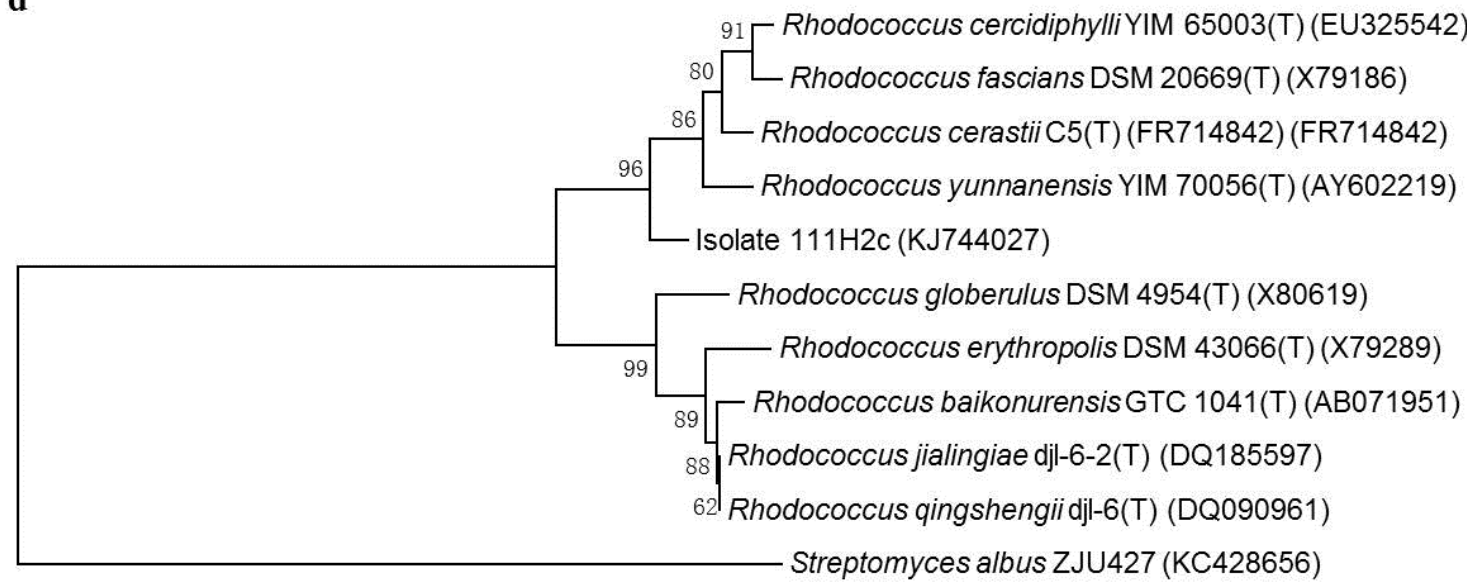

0.01 
e

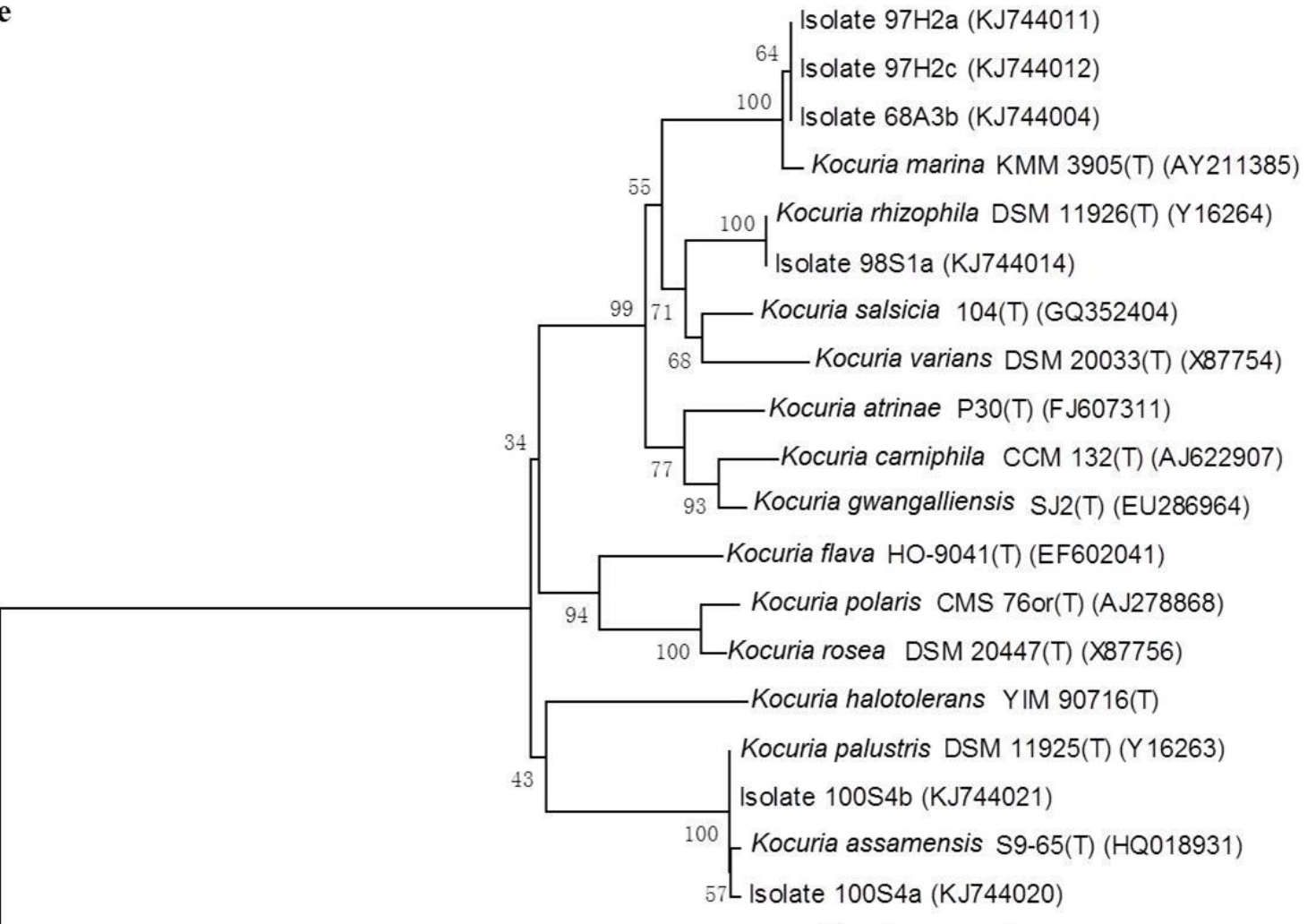

Streptomyces albus ZJU427 (KC428656)

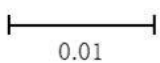

f

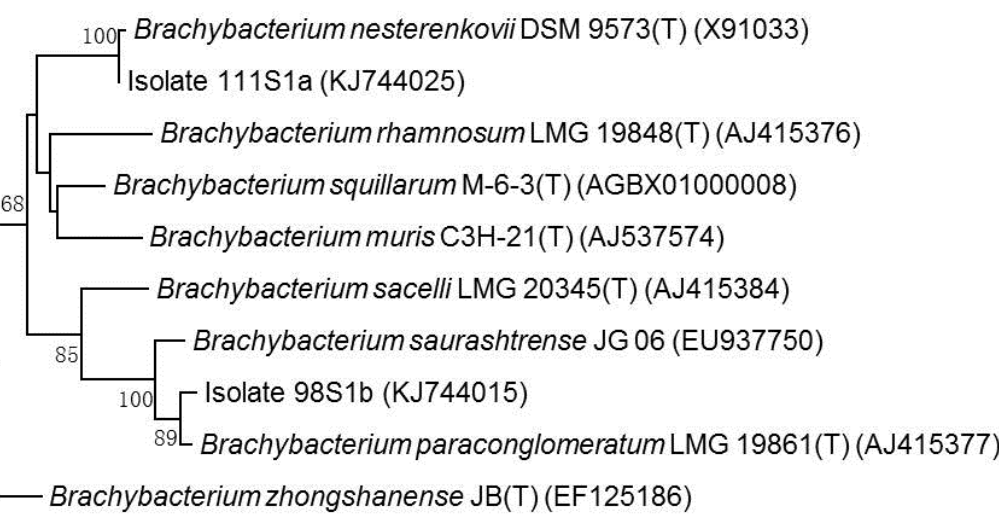

Streptomyces albus ZJU427 (KC428656)

0.01

g

5 f Isolate 100S2a (KJ744019)

97 Isolate $76 \mathrm{H} 2 \mathrm{a}(\mathrm{KJ} 744022)$

L Dermacoccus nishinomiyaensis DSM 20448(T) (X87757)

100

Dermacoccus abyssiMT1.1(T) (AY894323)

Dermacoccus profundiMT2.2(T) (AY894329)

68 Dermacoccus barathri MT2.1(T) (AY894328)

Streptomyces albus ZJU427 (KC428656)

0.005 
h

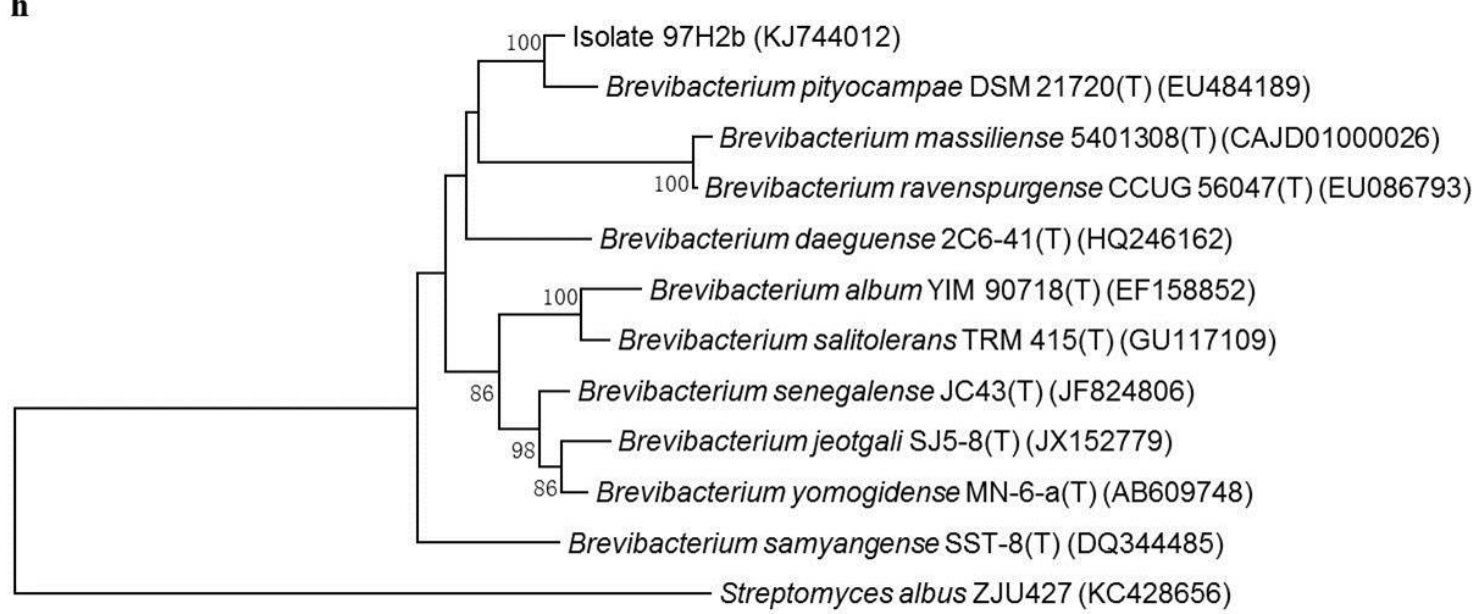

$\longmapsto$

i

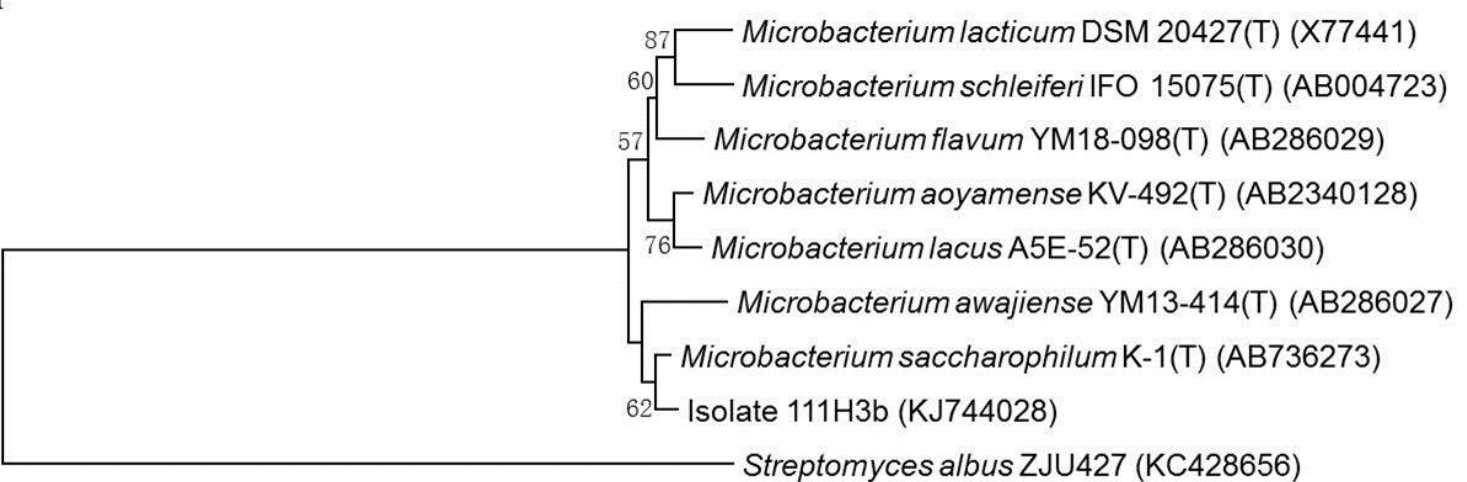

0.01

j

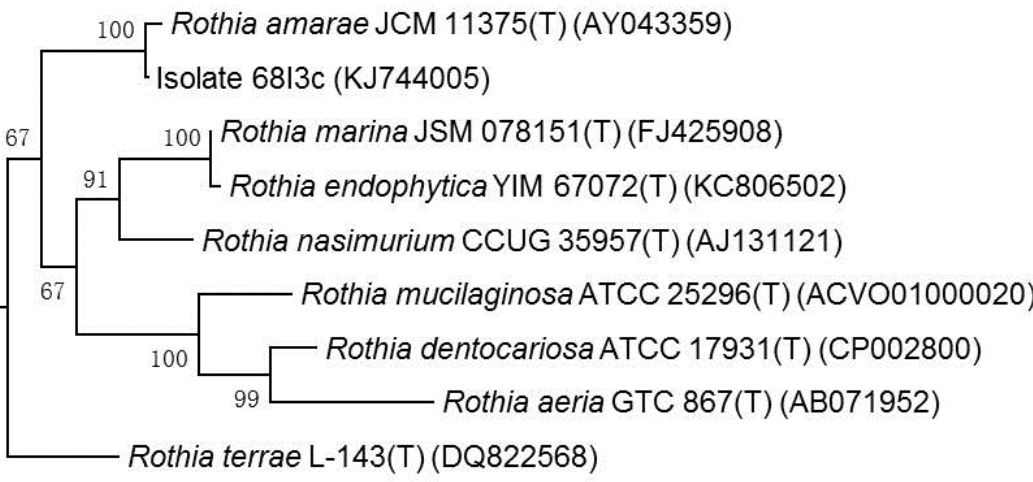

Streptomyces albus ZJU427 (KC428656)

$\longmapsto$

Figure 3: Neighbour-joining tree based on partial 16S rRNA gene sequences showing phylogenetic relationships between culturable rare Actinobacteria isolates and their relative type strains, (a) Streptomyces, (b) Micrococcus, (c) Micromonospora, (d) Rhodococcus, (e) Kocuria, (f) Brachybacterium, (g) Dermacoccus, (h) Brevibacterium, (i) Microbacterium and (j) Rothia.

In order to investigate the factor underlying the distribution of Actinobacteria from different biogeographical areas at Greenwich Island and Dee Island, PCA was performed according to the total species abundance data at the genus level. The result of PCA performed on soil samples based on actinobacterial community composition was presented in Figure 4. The first principal component explained $41.36 \%$ of the total variance, and the second principal component explained $17.95 \%$ of the total variance. By representing $59.32 \%$ of the total variance, a two-dimensional scores plot was presented. From the observation, the soil samples were distributed uncorrelated to the geographical locations When the presence of water activity examined as the explanatory variable, the soil samples of Pevima Lake showed the highest degree of 
variation of the actinobacterial community. The soil sample 97 (of the middle of the lake) was found to be distantly clustered with the other soil samples of lakeside. Furthermore, the variation of actinobacterial community underlie by the presence of water activity was also observed on the soils from Arturo Prat, in which the actinobacterial community in the soil sample with water activity (soil sample 68) was distantly related to the soil samples without water activity (soil samples 70 and 71). Although the water activity is absent in the soil sample 111, it was highly deviated from the cluster of all other soil samples and comprising of the most divergent actinobacterial community.

Observations (axes F1 and F2: $59.32 \%$ )
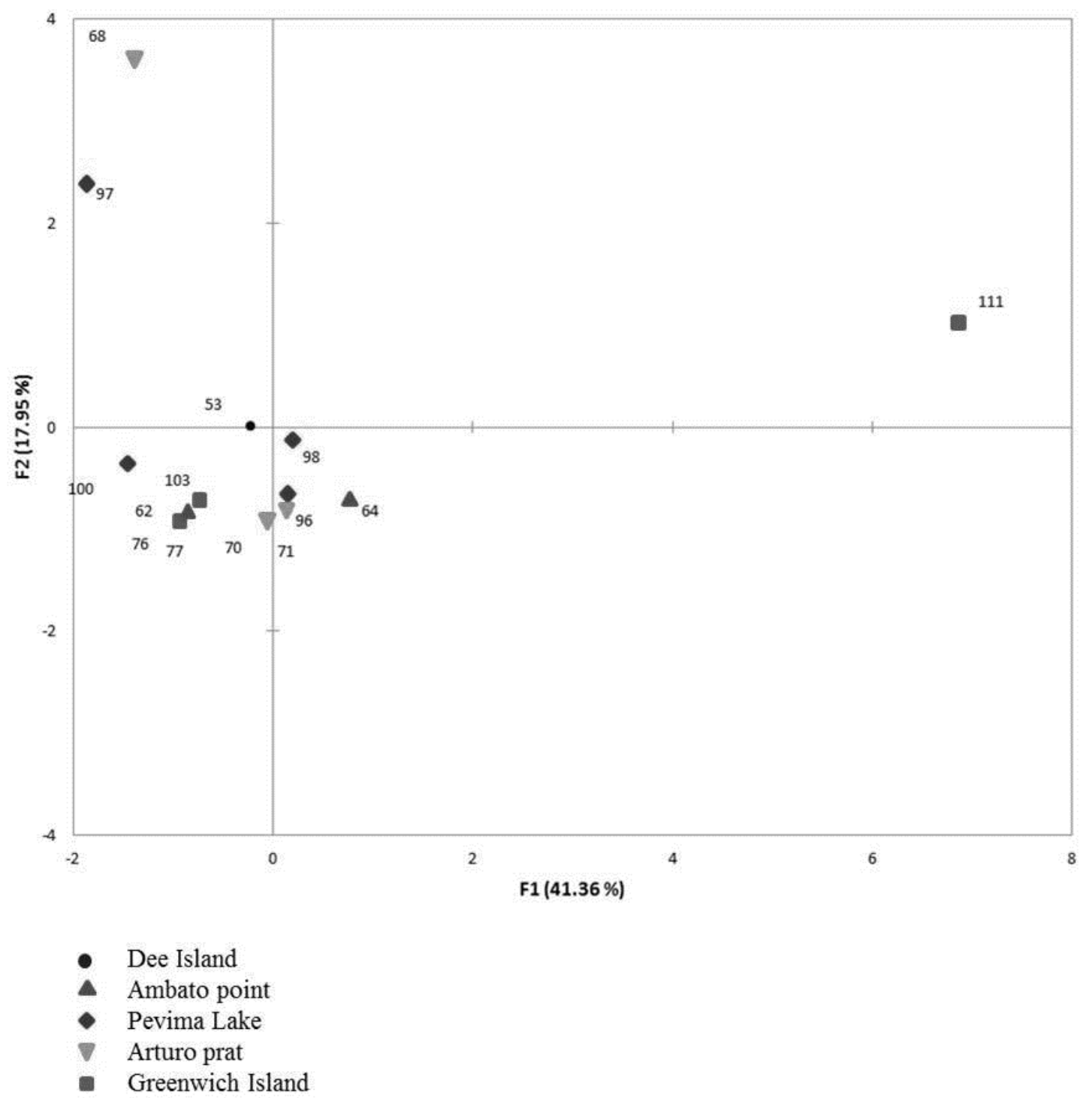

Figure 4: Ordination biplot generated by principal component analysis (PCA) of actinobacterial communities at genus level.

\section{Discussion}

Actinobacteria are widely distributed in the Antarctic environments (Smith 2006; Babalola et al. 2009; Foong et al. 2010; Ganzert et al. 2011; Pearce et al. 2012; Fan et al. 2013; Teo and Wong 2014). In the previous studies, the research of biodiversity on Greenwich Island was on mesophilic and psychrotrophic microfungi and most recently on the tellurite-resistant bacteria (Arenas et al. 2014). The main objective of this study was to isolate the pretreated Actinobacteria that were distributed in the soils of Greenwich Island and Dee Island.

As demonstrated by Pisano and co-workers, the pretreatment of environmental samples with phenol solution had greatly reduced the contamination of bacteria and fungi, in turn, favours development of slow-growing Actinobacteria. On the other hand, the percentage of recovery of Actinobacteria was increased by the inclusion of nystatin and cycloheximide to inhibit the growth of fungi, and nalidixic acid to eliminate the growth of non-mycelial bacteria. The success of selective isolation of Actinobacteria from soils will provide a more precise and significant enumeration of this soil microflora, and more importantly, capable of representing the composite picture of the population of rare Actinobacteria in the soil ecological studies. Then only after the well-established isolation techniques and enumeration of Actinobacteria from the environmental samples, numerous unknown taxa could be uncovered and thus improve our understanding of the diversity and distribution of Actinobacteria in Antarctic environment.

In the effort of isolating Actinobacteria from Greenwich Island, HVA was the most efficient isolation medium and capable of recovering the highest diversity of Streptomyces and rare Actinobacteria. In contrast with a study demonstrated by Li et al. (2012), HAV was found to be the least efficient isolation medium for the isolation of endophytic actinobacteria from environmental plant samples. The differences in between suggested selection of culture media is an important criterion for the isolation tasks with different environmental 
samples. In this study, $62 \%$ of the Actinobacteria isolates were recovered from HVA. Interestingly, all of the Streptomyces and Micromonospora isolates were only recovered on HVA. This finding could relate to the natural ecological role of Actinobacteria in recycling and decomposition of organic materials in soils, and their prevalence distribution in humus-rich soils (Goodfellow and Williams 1983; Ventura et al. 2007). Furthermore, Actinobacteria have been shown to utilize humic acid, a biological decomposition-resistant polymer, as the carbon and nitrogen source (Hayakawa 2008). HVA alone or with the supplement of antibiotics were shown to be efficient in the selective isolation of specific genera of Actinobacteria from various physical and chemical pretreatment of soil samples. This is due to the advantage of HVA offers proper growth and good sporulation of Actinobacteria in laboratory conditions.

The $\mathrm{pH}$ value is one of the key chemical parameters that shaped the distribution of microbes in soil (Lee 1991). Previous studies have shown that $\mathrm{pH}$ was affecting the community structure and diversity of bacteria in acidic soil (Lauber et al. 2009; Chu et al. 2010). Results from the present work on alkaline soils indicate the highest diversity of actinobacterial taxa was observed in the soils of slightly alkaline ( $\mathrm{pH}$ 7.4.-7.8). This finding is in accordance with the finding reported by Basilio et al. (2003), in which Actinobacteria were most prevalent in neutral and slightly alkaline conditions. The complexity of genera of Actinobacteria was reduced significantly as the alkalinity of soil increased to the extreme level. However, some isolates of the genera Streptomyces, Micrococcus and Micromonospora were viable and well-adapted to the extreme $\mathrm{pH}$ level (up to $\mathrm{pH}$ 9.5). Some of the members of these genera were previously found to be viable in various extreme alkaline environments and reported as alkaliphiles that produce novel biological substances (Jiang and Xu 1996; Vasavada et al. 2006; Mitsui et al. 2010; Bull 2011). Although Micrococcus was reported as one of the readily isolatable taxa from the Antarctic soils (Cameron et al., 1972), this study presented the first isolation of M. yunnanensis which is tolerant at the $\mathrm{pH} 9.5$, above the tolerance $\mathrm{pH}$ range (pH 6-8) reported previously (Zhao et al., 2009). This success of colonisation in high $\mathrm{pH}$ could probably due to the present of mechanisms in maintaining cytoplasmic pH (Padan et al. 2005). The employment of alkaline $\mathrm{pH}$ homeostasis is essential for alkaliphilic bacteria to have their proteins function optimally while sustaining the integrity of the structure. Recently, novel species of Streptomyces was isolated from saline-alkaline soils and were identified as alkaliphiles (Jiang et al. 2011; Zhang et al. 2013). This indicates the care selection of soil samples with elevated stressors of chemical parameters (such as $\mathrm{pH}$ ) will increase the novelty of isolation of Actinobacteria from targeted environments (Bull 2011). The nature characteristics of the soil, in this case, the $\mathrm{pH}$ level, had selected for different bacterial species which dominate the bacterial communities. Further work needs to be conducted to investigate the roles of these Actinobacteria in the soil microbial communities. This present work, therefore, provided a baseline platform for the selective isolation of Actinobacteria from Greenwich Island and Dee Island.

The present work was supported by the findings of other researchers that Streptomyces species was one of the most abundant, wide distributed and dominant Actinobacteria in the Antarctic soils (Saul et al. 2005; Pan et al. 2013). The high frequency of Micrococcus species isolated from total soil samples implied the well-adaptation in the harsh cold environment and played a significant role in the native niche of bacterial communities. Tiwari and Gupta (2012) had reviewed on the bioactive compounds reported from different genera of rare Actinomycetes isolated from various natural habitats and conclude that many of the successful antimicrobial agents currently available on the market are produced by rare Actinomycetes. The effort of isolating rare Actinobacteria is now gaining more attention and successful isolations of numerous new taxa of Actinobacteria from Antarctic were reported, such as new species of Nocardiopsis, Micromonospora, Streptomyces and new the genera Friedmanniella and Barrientosiimonas (Yassin et al. 1993; Schumann et al. 1997; Hirsch et al. 2004; Le Roes-Hill et al. 2009; Li et al. 2011; Lee et al. 2013). Low sequence similarity of 16S rRNA gene and distant phyletic lineage from the closest relative type strain showed by the rare Actinobacteria isolates in this study had assigned them to be putative new species of Actinobacteria. Furthermore, the rare Actinobacteria derived from the genus Micromonospora was recognized as one of the most prolific producers of novel secondary metabolites (Weinstein et al. 1963; Arcamone et al. 1980; Antal et al. 2005). Further investigation is needed for the validation of new species, such as DNA-DNA hybridization, which is one of the important criteria for the delineation of bacterial species, with the recommendation of relatedness values fall below $70 \%$ cut-off point (Wayne et al. 1987).

From the PCA analyses presented in Figure4, fluctuation of the diversity of Actinobacteria was correlated with the presence of water activity. The soil sample from the middle lake was distantly clustered from the soil samples of lakeside. This implies the different nutrient composition and physicochemical parameters of the center part of the lake which favour the changes in the bacterial community structure and diversity, compared to the lakeside. On the other hand, the effects of water activity and extreme UV index on the formation of divergent community structure were also examined (soil sample 68). Soil sample 111 was a soil mixture of decaying rock and near to the skua nest. The high divergent community structure observed could represent a nutrient-rich microhabitat for a high diversity of Actinobacteria to carry out decomposition and recycling processes of soil organic matters (Crawford 1988).

This study provides a base overview of the diversity of Actinobacteria at Greenwich Island and Dee Island. The metagenomics studies had demonstrated the prevalence of Actinobacteria in Antarctic soil (Teixeira et al. 2010; Aislabie et al. 2013). However, the number of culturable Actinobacteria only representing a tiny fraction of the total community of soil Actinobacteria, indicating numerous taxa of this group of bacteria are yet-to-be-cultured from Antarctic environments. Application of selective isolation can lead to the discovery of novel rare Actinobacteria from soil ecologies. The soil $\mathrm{pH}$ had exerted strong selection on the distribution of Actinobacteria in the soil. While an elevated diversity of actinobacterial community was examined with the presence of water activity in soil that served as a dynamic source for microbial interactions. Hence, in the future, it will be interesting to investigate the biosynthesis potential of the Actinobacteria recovered, especially the rare Actinobacteira. There is a hope where rare Actinobacteria may bear biosynthesis capacity of new antibiotics to combat the multidrugresistant human pathogens and emerging deadly diseases. The discovery of novel chemotypes with significant biological activity will become potential leads for drug discovery, which benefit the biotechnological and pharmaceutical industries.

\section{0}

\section{Declaration}

The authors declare no conflicts of interest in this work.

\section{Acknowledgements}

The authors are grateful to Geran Putra Malaysia (GP-IPS/2013/939800) and Yayasan Penyelidikan Sultan Mizan for the research funding and Department of Biomedical Science, Faculty of Medicine and Health Sciences, University Putra Malaysia for the facilities and laboratory infrastructure. Further appreciation to Malaysia Antarctic Research Programme and Instituto Anta rtico Ecuatoriano (INAE) for their support during the XI Ecuadorian Antarctic Expedition to "Pedro Vicente Maldonado" Research Station, Greenwich Island, South Shetlands Islands. 
Aislabie JM, Lau A, Dsouza M, Shepherd C, Rhodes P, Turner SJ (2013) Bacterial composition of soils of the Lake Wellman area, Darwin Mountains, Antarctica. Extremophiles 17:775-786.

Antal N, Fiedler HP, Stackebrandt E, Beil W, Ströch K, Zeeck A (2005). Retymicin, Galtamycin B, Saquayamycin Z and Ribofuranosyllumichrome, novel secondary metabolites from Micromonospora sp. Tü 6368. J Antibiot 58:95-102.

Arcamone F, Cassinelli G, DiMatteo F, Forenza S, Ripamonti MC, Rivola G, Vigevani A, Clardy J, McCabe T (1980) Structures of novel anthracycline antitumor antibiotics from Micromonospora peucetica. J Am Chem Soc 102:1462-1463.

Arenas FA, Pugin B, Henrı'quez NA, Arenas-Salinas MA, D1'az-Va'squez WA, Pozo MF, Muñoz, CM, Chasteen, TG, Pe'rez-Donoso JM, Va'squez CC (2014) Isolation, identification and characterization of highly telluriteresistant, tellurite-reducing bacteria from Antarctica. Polar Sci 8:40-52.

Atlas RM (1993) Handbook of microbiological media. CRC Press, Boca Raton.

Azman AS, Othman I, Velu SS, Chan KG, Lee LH (2015) Mangrove rare actinobacteria: taxonomy, natural compound, and discovery of bioactivity. Front Microbiol 6.

Babalola OO, Kirby BM, Roes-Hill L, Cook AE, Cary SC, Burton SG, Cowan DA (2009) Phylogenetic analysis of actinobacterial populations associated with Antarctic Dry Valley mineral soils. Environ Microbiol 11:566-576.

Baltz RH (2006) Combinatorial biosynthesis of novel antibiotics and other secondary metabolites in actinomycetes. SIM News 56:148-160.

Barrett JE, Virginia RA, Hopkins DW, Aislabie J, Bargagli R, Bockheim JG, Campbell IB, Lyons WB, Moorhead DL, Nkem JN, Sletten RS (2006) Terrestrial ecosystem processes of Victoria Land, Antarctica. Soil Biol Biochem 38:3019-3034.

Basilio A, Gonza' lez I, Vicente MF, Gorrochategui J, Cabello A, Gonza'lez A, Genilloud O (2003) Patterns of antimicrobial activities from soil actinomycetes isolated under different conditions of $\mathrm{pH}$ and salinity. J Appl Microbiol 95:814-823.

Becerril-Espinosa A, Freel KC, Jensen PR, Soria-Mercado IE (2013) Marine Actinobacteria from the Gulf of California: diversity, abundance and secondary metabolite biosynthetic potential. A Van Leeuw J Microb103:809-819.

Berdy J (2005) Bioactive microbial metabolites. J Antibiot 58:1-26.

Bredholdt H, Galatenko OA, Engelhardt K, Fjaervik E, Terekhova LP, Zotchev SB (2007) Rare actinomycete bacteria from the shallow water sediments of the Trondheim fjord, Norway: isolation, diversity and biological activity. Environ Microbiol 9: 2756-2764.

Bull AT (2011) Actinobacteria of the Extremobioshpere. In: Koki Horikoshi (ed) Extremophiles Handbook, Springer. pp 1203-1240.

Cameron RE, Morelli FA, Johnson RM (1972). Bacterial species in soil and air of Antarctic continent. Antarct J US 7:187-189.

Chu HY, Fierer N, Lauber CL, Caporaso JG, Knight R, Grogan P (2010) Soil bacterial diversity in the Arctic is not fundamentally different from that found in other biomes. Environ Microbiol 12:2998-3006.

Crawford DL (1988) Biodegradation of agricultural and urban wastes. In: Goodfellow M (ed) Actinomycetes in Biotechnology. Academic Press, London. pp 433-439.

Duarte AWF, Dayo-Owoyemi I, Nobre FS, Pagnocca FC, Chaud LCS, Pessoa A, Felipe MGA, Sette LD (2013) Taxonomic assessment and enzymes production by yeasts isolated from marine and terrestrial Antarctic samples. Extremophiles 17:1023-1035.

Fan J, Li L, Han J, Ming H, Li J, Na G, Chen J (2013) Diversity and structure of bacterial communities in Fildes Peninsula, King George Island. Polar Biol 36:1385-1399.

Felsenstein J (1985) Confidence limits on phylogeny: an appropriate use of the bootstrap. Evolution 39:783-791.

Foong CP, Ling CMWV, González M (2010) Metagenomic analyses of the dominant bacterial community in the Fildes Peninsula, King George Island (South Shetland Islands). Polar Sci 4:263-273.

Ganzert L, Lipski A, Hubberten HW, Wagner D (2011) The impact of different soil parameters on the community structure of dominant bacteria from nine different soils located on Livingston Island, South Shetland Archipelago, Antarctica. FEMS Microbiol Ecol 76:476491.

Gao B, Gupta RS (2005) Conserved indels in protein sequences that are characteristic of the phylum Actinobacteria. Int J Syst Evol Microbiol 55:2401-2412.

Gao B, Gupta RS (2012) Phylogenetic framework and molecular signatures for the main clades of the phylum Actinobacteria. Microbiol Mol Biol Rev 76:66-112.

Gesheva V, Negoita T (2012) Psychrotrophic microorganism communities in soils of Haswell Island, Antarctica, and their biosynthetic potential. Polar Biol 35:291-297.

Goodfellow M, Williams ST (1983) Ecology of actinomycetes. Annu Rev Microbiol 37:189-216.

Hayakawa M (2008) Studies on the isolation and distribution of rare Actinomycetes in soil. Actinomycetologica 22:12-19.

Hayakawa M, Iino H, Takeuchi S, Yamazaki T (1997) Application of a method incorporating treatment with chloramine-T for the selective isolation of Streptosporangiaceae from soil. J Ferment Bioeng 84:599-602.

Hayakawa M, Ohara Y (1987) Humic acid-vitamin agar, a new medium for the selective isolation of soil actinomycetes. J Ferment Technol 65:501-509.

Hayakawa M, Yoshida Y, Limura Y (2004) Selective isolation of bioactive soil actinomycetes belonging to the Streptomyces violaceusniger phenotypic cluster. J Appl Microbiol 96:973-981.

Hirsh P, Mevs U, Kroppendstedt RM, Schumann P, Stackebrandt E (2004) Cryptoendolithic actinomycetes from Antarctic sandstone rock samples: Micromonospora endolithica sp. nov. and two isolates related to Micromonospora coerulea Jensen 1932. Syst Appl Microbiol 27:166-274.

Hogg ID, Cary SC, Convey P, Newsham KK, O'donnell AG, Adams BJ, Aislabie J, Frati F, Stevens MI, Wall DH (2006) Biotic interactions in Antarctic terrestrial ecosystems: are they a factor? Soil Biol Biochem 38:3035-3040.

Hong K, Gao AH, Xie QY, Gao H, Zhuang L, Lin HP, Yu HP, Li J, Yao XS, Goodfellow M, Ruan JS (2009) Actinomycetes for marine drug discovery isolated from mangrove soils and plants in China. Mar Drugs 7:24-44.

Ivanov LL (2009) Antarctica: Livingston Island and Greenwich, Robert, Snow and Smith Islands. Scale 1:120000 topographic map. Troyan: Manfred Wörner Foundation. ISBN 978-954-92032-6-4.

Jadoon WA, Nakai R, Naganuma T (2013) Biogeographical note on Antarctic microflorae: Endenism and cosmopolitanism. Geoscience Frontiers 4:633-646.

Jiang CL, Xu LH (1996) Diversity of aquatic actinomycetes in Lakes of the Middle Plateau, Yunnan, China. Appl Environ Microbiol 62:249253.

Jiang Y, Cao YR, Wiese J, Tang SK, Xu LH, Imhoff JF, Jiang CL (2011) Streptomyces sparsus sp. nov., isolated from a saline and alkaline soil. Int J Syst Evol Microbiol 61:1601-1605. 
Kim OS, Cho YJ, Lee K, Yoon SH, Kim M, Na H, Park SC, Jeon YS, Lee JH, Yi H, Won S, Chun J (2012) Introducing EzTaxon: a prokaryotic 16S rRNA Gene sequence database with phylotypes that represent uncultured species. Int J Syst Evol Microbiol 62:716-721.

Küster E, Williams ST (1964) Media for the isolation of streptomycetes: starch casein medium. Nature 202:928-929.

Lane DJ (1991) 16S/23S rRNA sequencing. In: Stackebrandt E, Goodfellow M (eds) Nucleic acid techniques in bacterial systematics. Wiley, New York. pp 115-175.

Lauber CL, Hamady M, Knight R, Fierer N (2009) Pyrosequencing-based assessment of soil pH as a predictor of soil bacterial community structure at the continental scale. Appl Environ Microbiol 75:5111-5120.

Le Roes-Hill M, Rohland J, Meyers PR, Cowan DA, Burton SG (2009) Streptomyces hypolithicus sp. nov., isolated from an Antarctic hypolith community. Int J Syst Evol Microbiol 59:2032-2035.

Lee KE (1991) The diversity of soil organisms. In: Hawksworth DL (ed) The Biodiversity of Microorganisms and Invertebrates: Its Role in Sustainable Agriculture. CAB International, Wallingford, UK. pp 73-87.

Lee LH, Cheah YK, Sidik SM, Xie QY, Tang YL, Lin HP, Ab Mutalib NS, Hong K (2013) Barrientosiimonas humi gen. nov., sp. nov., anactinobacterium of the family Dermacoccaceae. Int J Syst Evol Microbiol 63:241-248.

Li J, Tian XP, Zhu TJ, Yang LL, Li WJ (2011) Streptomyces fildesensis sp. nov., a novel streptomycete isolated from Antarctic soil. A Van Leeuw J Microb 100:537-543.

Li J, Zhao GZ, Huang HY, Qin S, Zhu WY, Zhao LX, Xu LH, Zhang S, Li WJ, Strobel G (2012) Isolation and characterization of culturable endophytic actinobacteria associated with Artemisia annиa L. A Van Leeuw J Microb 101:515-527.

Margesin R, Miteva V (2011) Diversity and ecology of psychrophilic microorganisms. Res Microbiol 162:346-361.

Mitsui R, Hirota M, Tsuno T, Tanaka M (2010) Purification and characterization of vanillin dehydrogenases fromalkaliphile Micrococcus sp.TA1 and neutrophile Burkholderia cepacia TM1. FEMS Microbiol Lett 303:41-47.

Muñoz PA, Flores PA, Boehmwald FA, Blamey JM (2011) Thermophilic bacteria present in a sample from Fumarole Bay, Deception Island. Antarctic Sci 23:549-555.

Nichols D, Bowman J, Sanderson K, Nichols C, Lewis T, Mcmeekin T, Nichols PD (1999) Development with Antarctic microorganisms: culture collections, bioactivity screening, taxonomy, PUFA production and cold-adapted enzymes. Curr Opin Biotechnol 10:240-246.

Onofri S, Selbmann L, Hoog GS, Grube M, Barreca D, Ruisi S, Zucconi L (2007) Evolution and adaptation of fungi at boundaries of life. Adv Space Res 40:1657-1664.

Padan E, Bibi E, Ito M, Krulwich TA (2005) Alkaline pH homeostasis in bacteria: New insights. Biochim Biophys Acta 1717:67-88.

Pan SY, Annie Tan GY, Convey P, Pearce DA, Irene Tan KP (2013) Diversity and bioactivity of actinomycetes from Signy Island terrestrial soils, maritime Antarctic. Adv Polar Sci 24:208-212.

Pearce DA, Newsham KK, Thorne MAS, Calvo-Bado L, Krsek M, Laskaris P, Hodson A, Wellington EM (2012) Metagenomic analysis of a southern maritime Antarctic soil. Front Microbiol 3:1-13.

Pisano MA, Sommer MJ, Brancaccio L (1989) Isolation of bioactive actinomycetes from marine sediments using rifampicin. Appl Microbiol Biotechnol 31:609-612.

Pisano MA, Sommer MJ, Lopez MM (1986) Application of pretreatments for the isolation of bioactive actinomycetes from marine sediments. Appl Microbiol Biotechnol 25:285-288.

Saitou N, Nei M (1987) The neighbour-joining method: a new method for constructing phylogenetic trees. Mol Biol Evol 4:406-425.

Saul DJ, Aislabie JM, Brown CE, Harris L, Foght JM (2005) Hydrocarbon contamination changes the bacterial diversity of soil from around Scott Base, Antarctica. FEMS Microbiol Ecol 53:141-155.

Schumann P, Prauser H, Rainey FA, Stackebrandt E, Hirsch P (1997) Friedmanniella antarctica gen. nov., sp. nov., an LL-diaminopimelic acid-containing actinomycete from Antarctic sandstone. Int J Syst Bacteriol 47:278-283.

Shirling EB, Gottlieb D (1966) Methods for characterization of Streptomyces species. Int J Syst Bacteriol 16:313-340.

Smith JJ, Tow LA, Stafford W, Cary C, Cowan DA (2006) Bacterial diversity in three different Antarctic cold desert mineral soils. Microb Ecol 51:413-421.

Tamura K, Nei M, Kumar S (2004) Prospects for inferring very large phylogenies by using the neighbor-joining method. Proc Natl Acad Sci U S A 101:11030-11035.

Tamura K, Stecher G, Peterson D, Filipski A, and Kumar S (2013) MEGA6: Molecular Evolutionary Genetics Analysis Version 6.0. Mol Biol Evol 30:2725-2729.

Teixeira LCRS, Peixoto RS, Cury JC, Sul WJ, Pellizari VH, Tiedje J, Rosado AS (2010) Bacterial diversity in rhizosphere soil from Antarctic vascular plants of Admiralty Bay, maritime Antarctica. ISME J 4:989-1001.

Teo JKC Wong CMVL (2014). Analyses of soil bacterial diversity of the Schirmacher Oasis, Antarctica. Polar Biol 37: 631-640.

Tiwari K, Gupta RK (2012) Rare Actinomycetes: a potential storehouse for novel antibiotics. Crit Rev Biotechnol 32:108-132.

Ugolini FC, Bockheim JG (2008) Antarctic soils and soil formation in a changing environment: a review. Geoderma 144:1-8.

Vasavada SH, Thumar JT, Singh SP (2006) Secretion of a potent antibiotic by salt-tolerant and alkaliphilic actinomycete Streptomyces sannanensis strain RJT-1. Curr Sci 91:1393-1397.

Ventura M, Canchaya C, Tauch A, Chandra G, Fitzgerald GF, Chater KF, van Sinderen D (2007) Genomics of Actinobacteria: Tracing the evolutionary history of an ancient phylum. Microbiol Mol Biol Rev 71:495-548.

Wayne LG, Brenner DJ, Colwell RR, Grimont PAD, Kandler O, Krichevsky MI, Moore LH, Moore WEC, Murray RGE, Stackebrandt E, Starr MP, Tru" per HG (1987) Report of the ad hoc committee on reconciliation of approaches to bacterial systematics. Int J Syst Evol Microbiol 37:463-464.

Weinstein MJ, Luedemann GM, Oden EM, Wagman GH, Rosselet JP, Marquez JA, Coniglio CT, Charney W, Herzog HL, Black J (1963) Gentamicin, 1 a new antibiotic complex from Micromonospora. J Med Chem 6:463-464.

Williams ST, Davies FL (1965) Use of antibiotics for selective isolation and enumeration of actinomycetes in soil. J Gen Microbiol 38:251261.

Wilson K. (2001) Preparation of Genomic DNA from Bacteria. Curr Protoc Mol Biol 2.4.1-2.4.5.

Wynn-Williams DD (1996) Antarctic microbial diversity: the basis of polar ecosystem processes. Biodivers Conserv 5:1271-1293.

Yassin AF, Galinski EA, Wohlfarth A, Jahnke KD, Schaal KP, Trüper HG (1993) A new actinomycete species, Nocardiopsis lucentensis sp. nov. Int J Syst Bacteriol 43: 266-271.

Zakharova OS, Zenova GM, Zvyagintsev DG (2003) Selective isolation of actinomycetes of the genus Actinomadura from soil. Mikrobiologiia 72:110-113.

Zhang YG, Wang HF, Liu Q, Hozzein WN, Wadaan MAM, Cheng J, Chen YJ, Zhang YM, Li WJ (2013) Streptomyces fukangensis sp. nov., a novel alkaliphilic actinomycete isolated from a saline-alkaline soil. A Van Leeuw J Microb 104:1227-1233. 
Zhao GZ, Li J, Qin S, Zhang YQ, Zhu WY, Jiang CL, Xu LH, Li WJ (2009) Micrococcus yunnanensis sp. nov., a novel actinobacterium isolated from surface-sterilized Polyspora axillaris roots. Int J Syst Evol Microbiol 59:2383-2387. 